\title{
Z DZIEJÓW WALKI O TZW. RESTAURACJĘ AUTONOMICZNYCH ASPIRACJI PRUS KRÓLEWSKICH W XVIII WIEKU
}

„Przyznajemy, ̇̇e jesteśmy jedno $z$ Korona $w$ państwie $i$ jesteśmy członkami Korony, ale nie bez praw..."

Mikołaj Bażyński w 1490 r.
„Aczkolwiek kraj ten, Prusy, wcielony jest do Korony, to nie mniej kraj ten, Prusy, nie jest tym samym krajem, co Polska, ani Prusacy nie sa Polakami, ale to osobny $\mathrm{kraj} i \mathrm{ma}$ osobne prawa."

Eukasz Watzenrode w 1504 r.

,...jak jedno ciało posiada wiele członków, podobnie $i$ jedno Królestwo Polski obejmuje liczne prowincje $i$ ludy odmienne pod względem jezyka, obyczajów $i$ urządzeń..."

Radey pruscy do króla w 1537 r.

Dokumenty publiczne i publicystyka, traktaty naukowe i mowy sejmowe, uchwały stanów, decyzje sądowe i administracyjne, działania via facti i drogą prawną - oto mozaika wydarzeń, głosów i faktów w toku ewolucji historycznej, w której przebiegu niełatwo historykowi odróżnić głosy nostalgii za minionymi laty, nuty demagogii głoszącej to, co ma 
być, a nie to co rzeczywiście było, jednym słowem odróżnić skomplikowaną rzeczywistość ustrojową od wytworów ideologii i polityki. Dodajmy do tego pułapki terminologiczne, przemienność w podstawowych problemach tekstów łacińskich, niemieckich i polskich, problem właściwego rozumienia tychże przez tych co je tworzyli bądź używali i wreszcie przez tych, którzy po latach odcyfrowali stwierdzenia i precedensy przeszłości. Badacze XIX w. przystępowali do swej pracy uzbrojeni w aparat pojęciowy swoich czasów i często nie zdając sobie z tego sprawy w tłaczali rzeczywistość prawną i ustrojową epoki stanowej w siatkę pojęć swej epoki, epoki konstytucjonalizmu, liberalizmu, sukcesów życia parlamentarnego w społeczeństwie mieszczańskim. I wreszcie przypomnijmy krótko, że temat ten $\mathrm{z}$ wielu względów nie by 1 ani w XIX ani w XX w. kwestią czysto akademicką lecz budził żywe spory i zainteresowanie dwóch historiografii: niemieckiej i polskiej. Problematyka ustroju Prus Królewskich w ramach państwa polskiego, późniejszej Rzeczypospolitej Obojga Narodów, nie miała wbrew pozorom szczęścia w historiografii ${ }^{1}$. Brakowało i nadal brakuje nie tylko całościowego ujęcia owej bogatej problematyki ${ }^{2}$ ale nade wszystko studiów szczegółowych, konkretnych, które pozwoliłyby na właściwą ocenę wielu niejasnych bądź nie w pełni zasadnie rozwiązywanych spraw ${ }^{3}$. Stwierdzenie powyższe nie dotyczy wszystkich aspektów tematyki ani wszystkich epok w jej rozwoju. Możemy powiedzieć, iż dla ciekawego i ważkiego okresu lat 1454-1569 posiadamy w zasadzie wystarczające rozeznanie całościowe, bogatą literaturę przedmio$t u^{4}$ a prowadzone obecnie badania szczegółowe pozwolą wkrótce zamknąć

1 Por. co do dawniejszej literatury przedmiotu Wł. Konopczyński, Prusy Królewskie w unii z Polskq 1569-1772, ,Roczniki Historyczne”, III, 1927: ogólnoporównawczą i nowszą literaturę przedmiotu podają w oryginalnie skomponowanym wyborze tekstów K. Górski i J. Małłek, Prusy Królewskie i Książęce w XV i XVI w. część I (1466-1548), Toruń 1971. Dorzućmy tu dwie najnowsze prace tych autorów: K. Górs.ki, Stany $i$ unie państw na przykładzie Prus $i$ Polski $w$ XV $i$ XVI wieku, ZH, XXXIX, 1974, 3; J. Małłek, Próba likwidacji odrębności Prus Królewskich w roku 1530, ,Acta Universitatis Nicolai Copernici, Nauki Humanistyczno-Społeczne”, z. 58, Historia nr IX, Toruń 1973.

2 Jeżeli pominąć szkicowe zarysy, czy to niemieckie, czy też szkice S. Kutrzeby i Wł. Konopczyńskiego, oraz artykuły K. Górskiego, to brak nam monograficznego opracowania calości tematu. Ostatnia zwięzła próba historii politycznej Prus Królewskich sprawy ustrojowe traktuje nazbyt marginesowo: W. Odyniec, Dzieje Prus Królewskich 1454-1772, Zarys monograficzny, Warszawa 1972.

3 Nasuwa się tu $\mathrm{m}$. in. uwaga co do terminologii, problem nieadekwatności słownika XIX-XX w. do zjawisk epoki feudalnej. Termin ,samorząd” nie jest właściwym, także i ,autonomia” budzi uzasadnione obiekcje. J. Małłek, dz. cyt., 147, pisze, iż ,„[..] również nie jest najlepszym określeniem, bo zaczerpnięte jest ze słownika prawniczego XIX czy też $\mathrm{XX}$ w. Korzystamy tu $\mathrm{z}$ niego tylko $\mathrm{z}$ tych względów, gdyż na razie nie dysponujemy innym odpowiednim określeniem". Nb. stosowany niekiedy termin ,dążenia separatystyczne” jest błędny w tym sensie, iż aż po kres Rzeczypospolitej nie było poważnych sił, które by w Prusach Kr. dążyły do oderwania się od państwa polskiego, a jedynie broniły swych praw partykularnych. W XVIII w. ich dążenia stanowiły na płaszczyźnie ideologicznej walkę o restaurację ,,swobód krajowych" sprzed r. 1569.

${ }_{4}^{4}$ Poza w.w. także prace M. Biskupa, por. podsumowanie badań w: K. Górski, 
pozytywny bilans działań naszej historiografii na tym odcinku ${ }^{5}$. Także i. szczególna zgoła i wymagająca traktowania à part sprawa Gdańska zyskała sobie w badaniach głównie E. Cieślaka i S. Matysika nowe oświetlenie ${ }^{6}$. Obszerny przecież zakres problematyki ogólnej lat 1569-1772 pozostaje mało bądź i wcale nieruszonym w dotychczasowych badaniach. Stąd to nawiązując do ogólnych wskazań zawartych w pracach Karola Górskiego należy podjąc próbę zarysowania węzłowych zagadnień tej epoki celem wprowadzenia w ten sposób czytelnika do rozważań skoncentrowanych na kilku interesujących i dotąd nieznanych aspektach walki o tzw. restaurację autonomicznych aspiracji Prus Królewskich w XVIII wieku, które jaskrawy a paradoksalny wyraz znalazły w polityce Torunia i Gdańska lat 1764-1772 ?.

Charakteryzując globalnie literaturę niemiecką poświęconą problematyce ustrojowej Prus Królewskich powiemy, iż po pierwsze przyjmowała bezkrytycznie wypowiedzi polemiczne XVI-XVIII w. a pozostając pod ciśnieniem wielkiego autorytetu Gotfryda Lengnicha, interpretowała wydarzenia politycznoprawne tylko w oparciu o argumentację jednej ze stron toczących spór. Z reguły nie tylko nie rzucano tych wydarzeń na tło ustroju państwa polsko-litewskiego ale i odrywano badania od tła ogólnoeuropejskiego, prac i ustaleń O. Gierke, Brunnera czy też w okresie ostatnim wskazań E. Lousse ${ }^{8}$. Wypowiedziom i terminologii źródeł nadawano interpretację modernistyczną, formalistycznie prawniczą a w sumie ahistoryczną. Musiało to prowadzić do uproszczeń, fałszywych konstrukcji prawnych, koncepcji sprzecznych z podstawowymi elementami obrazu ustroju Rzeczypospolitej Obojga Narodów okresu po r. 1569. Po drugie zasadniczym tendencyjnym punktem wyjścia owych dziewietnastowiecznych a zwłaszcza dwudziestowiecznych (z okresu do 1945 r.) interpretacji była koncepcja nacjonalistyczna. W tym to ujęciu Prusy Królewskie jako kraj niemiecki wiodły w wiekach XVI-XVIII bohaterską

The Royal Prussia Estates in the second half of the XV th Century and their relations to the Crown of Poland, ,Acta Poloniae Historica”, 10 (1964).

5 W Toruniu J. Małłek obejmuje swymi badaniami okres od r. 1569 i w ten sposób zostanie zastąpiona zupełnie już przestarzała praca K. Slósarczyka (1927 r.). Wnikliwej weryfikacji wymagają też ustalenia Ch. A. Schierling, Der westpreussische Ständestaat 1570-1586, Marburg 1966.

${ }^{6}$ Obok powojennych artykułów S. Hoszowskiego i Wł. Czaplińskiego wymienić należy szczególnie: E. Cieślaka, Sprawa prawnego stosunku Gdańska do Polski $w$ czasie walk ustrojowych $w$ latach 1674-1678, w: Miscellanea Iuridica złożone w darze K. Koranyiemu w 40-lecie pracy naukowej, Warszawa 1961, tegoż, Społeczne podstawy ściślejszego zespolenia Gdańska z Polska w XVII i XVIII wieku, ZH, XXXI, 1966, 3; S. Matysika, O stosunku Gdańska do Polski i o ustroju Gdańska $w$ l. 1454-1793 (Stan i potrzeby badań), „Przegląd Zachodni”, 1954, nr 7/8.

7 Por. J. Dygdała, Polityka Torunia wobec wiadz Rzeczypospolitej w pierwszym okresie panowania Stanistawa Augusta (1764-1772), praca w druku, z której tezami miałem możność się zapoznać $\mathrm{w}$ toku procesu wydawniczego.

8 O rozwoju badań w tym zakresie por. E. Lousse, La Société d'Ancien Régime. Organisation et répresentation corporatives, I, Paris 1952, 1n. 
choé niepozbawioną klęsk walkę o utrzymanie niemieckiego ducha, kstóry broniono rzekomo na bastionach odrębności ustrojowych Prus Królewskich. Historyka zorientowanego w historii i mentalności świata feudalnego nie trzeba dziś przekonywać, iż ta wąska i tendencyjna koncepcja (którą - z odwrotnej strony barykady sugerowali się nieliczni tylko historycy polscy) zapoznawała całkowicie rzeczywistość historyczną ${ }^{9}$.

Ważnym założeniem metodologicznym $\mathrm{w}$ badaniach nad ustrojem Prus Królewskich wydaje się zwrócenie uwagi na fakt, iż w procesie tworzenia europejskich monarchii silnych, możliwie scentralizowanych, istniała $z$ reguły co do problematyki prerogatyw prawnych Korony, króla wobec poszczególnych terytoriów, stanów, czy też korporacji, sytuacja niejasna, obszar spraw spornych. Przywileje świata średniowiecznego wykreślały obraz rzeczywistości statyczny, opierały się na założonej niezmienności raz ustanowionego porządku prawnego, na szerokiej koncepcji praw nabytych i niezbywalnych bez wyraźnej zgody zainteresowanych (Ewigkeitsklausel w przywilejach). Z biegiem czasu nowe naglące konieczności rozwiązywano bądź w drodze porozumień z zainteresowanymi, bądź przez nowe interpretacje starych postanowień, bądź wreszcie poprzez łamanie dotychczasowych roszczeń i przywilejów partykularnych. W wielu krajach procesy te miały przebieg powolny i trudno nieraz mówić o rozwoju jednokierunkowym, co prowadziło do skomplikowanych i wielopłaszczyznowych i stale fluktuujących układów sytuacyjnych. Stąd też w badaniach nad ustrojem i prawem Prus Królewskich podjąć należy badania na trzech zasadniczych, przecinających się wzajemnie ale generalnie nie tożsamych płaszczyznach: płaszczyzna pierwsza, może stosunkowo najłatwiejsza $\mathrm{w}$ praktyce badania historycznego do ustalenia, to płaszczyzna sytuacji faktycznej. Bierzemy przykładowo dla danego okresu takie problemy jak kwestię, czy Gdańsk rzeczywiście wykonuje takie czy inne uprawnienia administracyjne i inne, czy miasta Prus Królewskich podlegają - i w jakim konkretnie zakresie - sądom koronnym, rozważamy stosowalność konstytucji sejmowych na terytorium Prus Królewskich, czy też pytamy się, czy przedstawiciele Prus byli powoływani na urzędy centralne koronne. Odpowiedzi usiłujemy konfrontować ze stanem prawnym (źródłami prawa), jeżeli istnieje możliwość ustalenia, co w danej kwestii jest stanem prawnym. Stan faktyczny sam przez się sprawy nie

9 Dorzucając tendencję nacjonalistyczną z punktu widzenia źródeł „,niemiecka nauka historyczna nie wyszła dotąd poza streszczenie wyników dociekań Lengnicha", jak wskazywał R. Lutman, Położenie prawno-polityczne Gdańska w dawnej Polsce, „Rocznik Gdański”, I (1927) 60. Do dawnych (dziś z reguły bezwartościowych) prac Löschina, Kaufmanna, J. N. Pawłowskiego, P. Simsona dorzucić należy nowsze prace E. Carstena czy E. Keysera. Stosunkowo rozważnym tonem historyka wyróżniał się O. Günther, Die Verfassung der Stadt Danzig in polnischer Zeit (1454-1793) und als Freistaat (1807-1814), Danzig 1919, ale i on jako wydawca Lengnicha nazbyt sugerował się jego prawniczymi wywodami. 
przesądza, jeżeli bowiem narusza konkretną i nadal ${ }^{10}$ obowiązującą normę prawną to $\mathrm{w}$ takim razie mamy do czynienia jedynie $\mathrm{z}$ bezprawną uzurpacją (i tak było $\mathrm{z}$ reguły w Gdańsku). Jeżeli brak szczegółowych przepisów, stan faktyczny uznać raczej należy za stan prawny, jeżeli miał charakter notoryjny i nie był kwestionowany przez jedną ze stron. Rzecz ta musi budzić wiele szczegółowych wątpliwości. I wreszcie płaszczyzna trzecia badań to studium twierdzeń prawnych stron zainteresowanych, które z jednej strony mogą nam służyć (przy bardzo ostrożnym procesie krytyki źródła) jako informacja co do obowiązującego stanu prawnego, bądź jako wyraz roszczeń a nawet programów ustrojowych o wymowie ideologicznej rzutującej często przeszłość jako argument za celem do osiągnięcia a nie mający aktualnie żadnego pokrycia $\mathrm{w}$ rzeczywistości. Przekonamy się, iż to strona zwłaszcza gdańska (a w XVIII w. i toruńska) celowała $w$ taktyce ubierania tolerowanych przez długi czas i niedostrzeganych uzurpacji $\mathrm{w}$ barwy bardzo niekiedy pomysłowych konstrukcji prawnych po to, by nie bez emfazy i demagogii zwalczać wszelkie próby powrotu do dotychczasowego stanu prawnego. Jak więc widzimy, nie w każdej sytuacji będzie istniała możliwość stworzenia jednolitego, precyzyjnego i pozbawionego elementów niejasności obrazu ustroju Prus Królewskich. Nie ulega dla nas żadnej wątpliwości, iż stanowiły one w ramach Korony kraj, a następnie prowincję o względnie znacznych odrębnościach partykularnych. Jak daleko sięgały przecież owe odrębności rozgorzała właśnie w XVIII w. szczególna, choć zgoła bezkrwawa walka, w której podstawowym elementem były druki polemiczne, rozprawy pozornie wielce naukowe, manifesty i remanifesty, protestacje, memoriały i deklaracje. Obie strony, zgodnie zresztą z narastającym ewolucyjnie stanem prawnym sięgać musiały i sięgały aż po wydarzenia XV-XVI w., w nich szukały argumentów dla swoich twierdzeń i dążeń. Wystąpienia nie tyle z XV-XVI w., co owe druki polemiczne z XVIII w. traktowały Prusy Królewskie jako państwo samodzielne, połączone jedynie unią personalną z Koroną. Stosowano wielokrotnie termin Herzogthum na określenie terytorium Prus Królewskich, wskazywano jego rzekomą samodzielność wobec Korony przed r. 1569, odrzucano literalnie zawarte $\mathrm{w}$ przywilejach królewskich pojęcie inkorporacji Prus w skład ziem Korony. Za tego typu poglądami szły i twierdzenia o rzekomo międzynarodowym stanowisku prawnym samego Gdańska ${ }^{11}$.

10 Warto zwrócić uwagę na dość niejasny problem, typowy dla doby feudalnej, iż wygaśnięcie dawnego przepisu prawa względnie jego moc obowiązująca pozostawały dyskusyjne w świetle ówczesnych źródeł prawa także i w dobie państwa nowożytnego, por. o tych problemach uwagi H. Grajewskiego, Granice czasowe mocy obowiazujacej dawnego prawa polskiego, Łódź 1970, zwłaszcza s. 93 n. Sprawa cała wymagałaby szczegółowych studiów na tle doktryny polskiej XVI-XVIII w.

11 Ocenił tę sprawę raz jeszcze S. Matysik w zarysie Dziejów Gdańska w pracy zbiorowej: Gdańsk. Jego dzieje i kultura, Warszawa 1969. Na s. 40 czytamy: ,Sy- 
Były to wszystko bądź twierdzenia tendencyjne, bądź niewnikające.w istotę sytuacji typowych dla wielkich monarchii stanowych w Europie: dla państwa polskiego proces konsolidacji i porządkowania spraw ustrojowych przeciągnął się $\mathrm{w}$ tym zakresie aż do r. 1569. W okresie powojennym Karol Górski ${ }^{12}$ po raz pierwszy zastosował porównawczo wiedzę o organizmach stanowych europejskich do sytuacji Prus Królewskich ${ }^{13}$. Oto tezy, które wynikają z dotychczasowego stanu wiedzy o przedmiocie dla okresu 1466-1569:

1. W $1454 \mathrm{r}$. Polska nie była już dziedzicznym państwem dynastycznym, a stany pruskie wobec tego nie tyle wybierały sobie nowego władce, co przyłączały się do Korony. W tej umowie stron, która znalazła wyraz w treści przywilejów królewskich udział polskich czynników państwowych odgrywał rolę zasadniczą. Tak więc Prusy Królewskie nie zostały połączone unią personalną z Koroną lecz:

2. zostały do niej - zgodnie z tenorem aktów z 1454 r. - ,inkorporowane”. Termin ,inkorporacja” był wielokrotnie błędnie rozumiany jako synonim likwidacji wszelkich praw i odrębności partykularnych terytoriów inkorporowanych. Istniały różne typy inkorporacji. W każdym razie nie była ona $\mathrm{w}$ tym sensie przeciwieństwem unii, by miała nieuchronnie podbawiać dane terytorium wsdelkiej odrębności ${ }^{14}$. Stąd też Karol Górski używa terminu „unia stanowa”, która jednakże nie ma ani chronnie pozbawić dane terytorium wszelkiej odrębności ${ }^{14}$. Stąd też realną, bowiem inkorporacja niosła za sobą nieuchronnie wyraźną (choć niesprecyzowaną w szczegółach) podległość - pewną niższość terytorium inkorporowanego ${ }^{15}$. Tak więc skonkludujemy, iż inkorporacja nie znosiła zasadniczych odrębności ustrojowych Prus Królewskich, jego praw znacznie przez przywileje królewskie pomnożonych. Wyrazem ówczesnym tych odrębności były osobne zgromadzenia stanowe, organy administracyjne, własne prawo sądowe itd. ${ }^{16}$

tuacja prawna Gdańska - w całym tym okresie i później, mimo dalszych przywilejów i ustaleń królewskich - nie była wystarczająco jednoznacznie i precyzyjnie określona. A Radzie gdańskiej wcale nie zależało na bliższym określeniu tej sytuacji, która - posiadając liczne luki i niecomówienia - pozwalała gdańszczanom na dogodną, elastyczną interpretację przywilejów i własnych uprawnień". Nb. doktryna polska (Chwałkowski, Ostrowski i in.) nie przyznawała Gdańskowi w zasadzie większych praw niż innym miastom królewskim.

12 Por. zwłaszcza tegoż, Problematyka dziejowa Prus Królewskich, ZH, XXVIII, 1963,2 .

13 Por. także G. Schramm, Staatseinheit und Regionalismus in Polen-Litauen (15-17 Jahrhundert), Forschungen zur Ost-Europäische Geschichte, 1966, oraz D. Gerhard, Regionalismus und ständisches Wesen als ein Grundthema europäischer Geschichte, „Historische Zeitschrift”, 174, 1952.

11 Warto pamiętać, iż ustrój stanowy Prus Kr. w tym momencie był daleki od krystalizacji i instytucje stanowe w XV-XVI w. podlegały stałej ewolucji.

1.5 Używając niemieckiej terminologii dla doby państwa stanowego powiemy, iż Prusy Kr. jako kraj były formacją korporacyjną w ramach polskiego państwa (Territorialstaat) czyli Korony jako całości.

16 Zasadniczy dla przyszłości był problem stosunku rady pruskiej do organów 
3. Tak więc Prusy Królewskie weszły w skład Korony jako nowy „kraj” (Land) a więc coś więcej niż ziemia bądź prowincja w prawie publicznym polskim, jednakże nigdy nie uzyskały sobie ani pozycji niezależnej od Korony ani pozycji formalnie równorzędnej, jaką utrzymała w toku ewolucji Litwa. Czym był „kraj” w terminologii stanowej? Zgodnie z definicją Lousse'a był to korporacyjny związek stanów danego terytorium ${ }^{17}$.

W toku licznych sporów końca XV w. zaakcentowane zostały odrębności Prus Królewskich, „nastąpiło umocnienie partykularyzmu pruskiego" 18. Wiek XVI wraz z procesem walki szlachty o wszechwładzę w państwie realizowanej $\mathrm{w}$ formie sporu o tzw. egzekucję praw przyniósł odwrócenie kierunku przemian: w oparciu o rosnącą wspólnotę interesów społecznych i politycznych szlachty Korony, W. Ks. Litewskiego, a także i właśnie szlachty pruskiej ${ }^{19}$ narastały dążenia do zabezpieczenia interesów całości poprzez likwidację pewnych odrębności i organizację instytucji ogólnopolskich. Ten program unifikacji co do Prus Królewskich został w dużej mierze zrealizowany decyzjami królewskimi w 1569 r., który to rok otworzył nową epokę w dziejach ustrojowych Prus Królewskich ${ }^{20}$.

Królowie polscy zawsze traktowali Prusy w ramach Korony i już przed r. 1569 nigdy nie składali odrębnej przysięgi wobec stanów pruskich. Ściślejszego zespolenia Prus Królewskich z Koroną dokonał dekret Zygmunta Augusta wydany na sejmie lubelskim po zapozwaniu stanów pruskich o egzekucję dawnych praw ${ }^{21}$. Mimo pewnych protestów (inspi-

centralnych w Koronie. K. Górski (Monarchia polska a stany Prus Królewskich w II połowie XV wieku, w: Prace $z$ dziejów Polski feudalnej ofiarowane Romanowi Grodeckiemu w 70 rocznice urodzin, Warszawa 1960, 283) wskazuje, iż przywileje nie wyjaśniały, czy radcy pruscy mają obradować z królem odrębnie czy wraz z radą koronną: „W czasie wojny trzynastoletniej rozstrzygano sprawy wspólnie, a nieraz rada koronna, obradując nad sprawami państwa, decydowała o sprawach pruskich". Spory w tej kwestii były żywe pod koniec rządów Kazimierza Jagiellończyka.

17 Por. przekład wywodów E. Lousse w: K. Górski, J. Małłek, dz. cyt., 23 n.

18 J. Małkek, dz. cyt., 146. Por. uwagi modelowe H. G. Koenigsberger, The State General of the Netherlands before the Revolt, w: Etudes présentées à la Com. Intern. pour l'histoire des Assemblées d'Etats, XVIII, Louvain-Paris 1958, 148: ,[...] the relationship between crown and estates was ultimately a question of power. The claims of both sides had finally to be resolved by the victory of one or the other and, until that happened - as it happened sooner or later everywhere in Europe-there was bound to be a shifting balance of power".

12 Od lat dwudziestych XVI w. szlachta Prus Kr. ustosunkowuje się z czasem coraz przychylniej do unifikacyjnych dążeń Korony wbrew stanowisku miast i niektórych dostojników krajowych.

${ }_{20}$ Był to zarazem, jak wiemy, decydujący rok dla zamknięcia budowy struktury państwa polsko-litewskiego, której uwieńczenie przyniosły Artykuły Henrykowskie. Por. porównaweze uwagi G. Rhode, Stände und Königthum in Polen/Litauen und Böhmen-Mähren. Bemerkungen zur Entwicklung ihres Verhältnisses vom 16. bis ins 18. Jahrhundert, ,Jb. f. Geschichte Osteuropas”, NF, 12, 1964, 2.

21 Nb. obie strony już w 1568 r. zgadzały się, by król rozstrzygnął sporne wątpliwości co do stosowania przywilejów i organizacji związków Prus Królewskich 
rowanych przez wielkie miasta) stany pruskie zaakceptowały decyzje królewskie, które zresztą poza ujednoliceniem na szczeblu ogólnokrajowym reprezentacji stanowej nie szły zbyt daleko w procesie unifikacji utrzymując gros dotychczasowych odrębności ${ }^{22}$. Jeżeli szlachta pruska była w zasadzie gotowa poddać się decyzjom królewskim, to także i dlatego, że fundamentem decyzji unifikacyjnych w państwie polsko-litewskim było dopuszczenie przedstawicieli poszczególnych terytoriów do udziału w rzeczywistych rządach całym państwem. Stąd i proces unifikacji, jak będą ubolewać w XVIII w. rzecznicy separatyzmu - natrafiał na większy opór tylko ograniczonych sił społecznych, bowiem w rzeczywistości dla panującej w państwie szlachty rozszerzał, a nie zawężał, uprawnienia ${ }^{23}$.

Jeżeli epoka lat 1569-1772 nie przyniesie już żadnych zasadniczych zmian w sytuacji ustrojowej Prus Królewskich, to przecież wyróżnić w niej możemy - w obecnym stanie badań dość hipotetycznie - następujące fazy rozwojowe:

1. Przez cały okres I połowy XVII w. obserwujemy narastający już od końca wieku XVI ${ }^{24}$ powolny, ale wyraźny proces unifikacji urządzeń ustrojowych i życia politycznego Prus Królewskich i Korony ${ }^{25}$. Po roku 1569 Prusy Królewskie z pozycji „kraju” w ramach Korony schodzą do roli jednej $\mathrm{z}$ prowincji ${ }^{26} \mathrm{z}$ tym, iż $\mathrm{w}$ różnych sytuacjach - zgodnie

z Koroną i decyzja królewska stanowiła niewątpliwie uprawnioną formę interpretacji przywilejów pruskich.

22 Mimo wszystko, jeżeli do r. 1569 mówić możemy o Prusach Kr. jako „kraju”, od tej daty zunifikowanie odgórne formy rządów powoduje, iż Prusy Kr. zachowując znaczne prawa i odrębności partykularne nie różnią się zasadniczo od innych części składowych Korony.

${ }^{23}$ O tym dobitnie pisał $\mathrm{w}$ swoim czasie Konopczyński, dz. cyt., 119, podkreślając, iż ,asymilacja ustrojowa po roku 1569 odbywała się także bez jakichkolwiek planowych wysiłków ze strony Krakowa czy Warszawy". Zyczliwej informacji doc. J. Małłka zawdzięczam znajomość interesującego tekstu broniącego swobód prowincji, a spisanego po polsku ok. 1575 r. (WAP Gdańsk, sygn. $300 \mathrm{Rj}$ nr 24 . Bibl. Archivi, Varia, p. 25-27) pt. Artykuty, $w$ których ziemie $i$ miasta pruskie obciązone sq. Inspirowany przez władze gdańskie autor (?) zwracał się zapewne do ogółu szlachty $\mathrm{w}$ obronie praw pruskich atakując nade wszystko obowiązek udziału w sejmie koronnym, naruszanie praw indygenatu ,,[...] jako teraz Cromerus niejaki, nie wiedzieć skąd jest, najprzedniejsze biskupstwo helsperskie w Prusiech trzyma [...]", egzekucję dóbr rozciągniętą na terytorium Prus, wymierzanie podatków przez sejmy koronne itd. itd.

24 Sprawy te wymagają szczegółowych badań $\mathrm{i}$ to nie tylko $\mathrm{w}$ zakresie akt sejmikowych Prus Królewskich, bowiem nie ulega wątpliwości, iż w uchwałach grudziądzkich często ,dla świętego spokoju” umieszczano principia, których propagatorami pozostały już tylko wielkie miasta. Co do ogromnego materiału sejmikowego por. K. Górski, Inwentarz aktów sejmikowych Prus Królewskich (1600-1764), TNT, Fontes 34, I-II, Toruń 1950.

${ }_{25}$ Konkretne spory wybuchają $w$ zasadzie tylko w trzech przypadkach, a to o indygenat, podatki i decyzje o nowych cłach, oraz sprawy monetarne: „Na tych trzech szańcach swej odrębności stali nasi Prusacy wytrwale". W. Konopczyński, dz. cyt., 125 .

${ }_{26}$ Pojęcie prowincji nie było $w$ prawie koronnym bliżej rozbudowane. Sejmik pruski w XVII w. z reguły mówi o iura et privilegia Terrarum Prussiae. Pisano przecież nieraz o Iuribus Provinciae. 
z dotychczasową praktyką polskiego prawa publicznego - mówi się tylko o dwóch prowincjach i wówczas Prusy Królewskie podobnie jak i Mazowsze są zaliczane do prowincji wielkopolskiej ${ }^{27}$. Z najważniejszych odrębności ustrojowych prowincji utrzymały się w tym czasie następujące: I. Odrębna organizacja sejmiku pruskiego o charakterze sejmiku generalnego ${ }^{28}$, działalność Rady Pruskiej (Landesrat) ${ }^{29}$. II. Zasada indygenatu pruskiego wielokrotnie potwierdzana, sporna i łamana przez władców, zwłaszcza w XVIII w. ${ }^{30}$. III. Odrębności organizacji administracji i sądownictwa ${ }^{31}$. IV. Z reguły pomija się wśród wyliczanych odrębności problem odrębnej organizacji kościelnej, która weszła w życie pod Zygmuntem Augustem, którego przywilej otrzymywania komunii pod dwoma postaciami został następnie utożsamiony $\mathrm{z}$ prawną wolnością kultu religii luterańskiej i katolickiej. Nie powstał przecież terytorialnie zorganizowany kościół luterański.

2. W okresie od $1660 \mathrm{r}$. tendencje unifikacyjne załamują się, co zresztą jest nade wszystko wyrazem ogólnopaństwowych procesów decentralizacyjnych $\mathrm{w}$ państwie polsko-litewskim ${ }^{32}$. W nowej sytuacji zwłaszcza

27 I tak od Jana III posłowie i senatorowie pruscy wliczani byli do prowincji wielkopolskiej $\mathrm{w}$ ramach sesji prowincjonalnych. Podobnie było $\mathrm{w}$ wielu innych sprawach, związanych z Trybunałem Koronnym itd. W XVIII w. była to już praktyka utarta.

${ }_{28}$ W innych ziemiach Rzeczypospolitej dawniejsze sejmiki generalne (prowincjonalne) przestały w XVII w. działać jako instytucja stała o określonych kompetencjach. Odrębna rola miast w sejmiku pruskim nadawała mu odmienny charakter, jednakże królowie po r. 1569 zlikwidowali prawo dowolnego zbierania się sejmików bez wezwania króla (Wyjątki: 1677, 1702, 1716). Sprawa ta wymagałaby dalszych badań, jednakże w XVII w. - kiedy sejmik pruski stracił swe dawniejsze kompetencje sądowe - ustała też racja bytu regularnych corocznych posiedzeń. Pewien renesans obserwujemy dopiero od 1640 r., a zwłaszcza w dobie „rządów sejmikowych" w Rzeczy pospolitej.

${ }_{29}$ W XVII w. instytucja ta wegetowała jedynie na skutek usilnych starań wielkich miast, które $\mathrm{w}$ ten sposób zapewniały sobie wpływ na życie polityczne prowincji. Ostatni raz w $1647 \mathrm{r}$. doszło do realizacji prawa tajnej audiencji reprezentantów stanów Prus Kr. u króla. Odtąd jedynie wielkie miasta powoływały się na prawo otrzymywania audiencji u króla w swych sprawach. Dodać przecież trzeba, iż król, jako najwyższy zwierzchnik miast królewskich, podobnie przyjmował delegatów Krakowa, Lwowa czy Poznania.

so Wbrew późniejszym twierdzeniom Lengnicha i innych autorów nadawanie indygenatu przeszło na sejm, a więc było wyrazem kompetencji tej instytucji także i dla terytorium Prus Kr. Nb. laudum grudziądzkie z $1666 \mathrm{r}$. wzywające, by indygenaty były nadawane tylko na podstawie rekomendacji sejmików wojewódzkich, nie było przestrzegane. Por. ogólnie S. Grodziski, Obywatelstwo w szlacheckiej Rzeczypospolitej, Kraków 1963, 119-122.

${ }^{31}$ Odrębne prawo sądowe dla poszczególnych stanów bądź terytoriów było zjawiskiem znanym powszechnie w Rzeczypospolitej. Unifikacja sądownictwa, a zwłaszcza spory miast $\mathrm{z}$ instancjami sądowymi Korony nie były dotąd przedmiotem studiów. Kierownicza siła prowincji, szlachta, poszła w tej dziedzinie, podobnie jak i co do administracji lokalnej, na ogólnopolską niemal całkowitą unifikację. Wśród odrębności wspomnijmy, iż pewne szersze kompetencje posiadali wojewodowie, kasztelanowie, a podkomorzowie mieli dodatkową kompetencję $w$ postaci zarządu dóbr królewskich w województwie.

${ }_{32}$ Por. ogólnie interesujące uwagi A. Lityńskiego, W kwestii suwerenności wewnętrznej Rzeczplitej w epoce oligarchii, w: Prace naukowe Uniwersytetu Slaskiego, 
wielkie miasta walczą zdecydowanie o swe partykularne pozycje, choć ze zmiennym szczęściem, o czym świadczą dzieje Gdańska w dobie rządów Jana III ${ }^{33}$.

3. W dobie rządów królów saskich obserwujemy wielokrotne próby ze strony władzy centralnej wzmocnienia jej uprawnień na terenie Prus Królewskich. Owe działania królów saskich skoncentrowały się zresztą głównie w walce z Toruniem i Gdańskiem ${ }^{34}$. Warto zresztą podkreślić, iż poza ciągle sporną kwestią indygenatów ${ }^{35}$ szlachta pruska I poł. XVIII w. była poza pewnymi wyjątkami (grupy protestanckie) w pełni zintegrowane społecznie, politycznie i mentalnością swoją związana z ogółem szlacheckim Rzeczplitej. Ta narastająca faktycznie unifikacja kraju wywołała w tym okresie nasilenie się obronnych tendencji separatystycznych, które znalazły wyraz w bogatszej niż w XVII w. ${ }^{36}$ literaturze prawniczej, historycznej i politycznej, do której to kwestii wrócimy w drugiej części rozważań.

1971, Pr. Prawn. nr 2, który wskazuje, iż problem stosunku sejm-sejmiki z punktu widzenia suwerenności uchwał tych organów jest trudny do rozwikłania, choć ogólnie rola sejmu była przeważającą, ale nie co do spraw podatkowych (dla okresu 1660-1717); oraz J. K. Hoensch, Sozialverfassung und politische Reform. Polen im vorrevolutionären Zeitalter, Köln-Wien 1973, 393. Jeżeli stany pruskie (a zwłaszcza literatura stanowa w XVIII w.) głosiły, że podatki przyjmują tylko stosownie do decyzji sejmiku grudziądzkiego i niekiedy protestowały przeciw konstytucjom sejmowym podjętym za zgodą posłów pruskich (por. np. protest z $1671 \mathrm{r}$. K. Górski, Inwentarz aktów sejmikowych..., I, 151) to doprowadzały tylko do krańcowych granic logikę ustroju Rzeczypospolitej, co i zasady quod omnes tangit. Był to także ogólnoeuropejski problem stanowy; por. prace A. Marongiu, E. Lousse'a, G. Griffithsá. H. G. Koenigsberger, Estates and Revolutions. Essays in Early Modern European History, Ithaca-London 1971, 231 rozważając problem plena potestas delegatów, pisze: „The restrictions which the estates imposed in the powers of their deputies were a very useful weapon in the defence of local and provincial privileges". Należy przecież odrzucić pogląd, iż konstytucje sejmowe generalnie bez zgody Grudziądza nie obowiązywały, bowiem z reguły obowiązywały. Por. interesujący przykład uchwały grudziądzkiej (w instrukcji dla posłów) z 15 XII 1678: „Petitur tandem, ut ius illud Ordinis equestris Terrarum Prussiae correctum nova constitutione approbetur". Swiadczy ona o poglądzie, iż dopiero moc konstytucji sejmowej wprowadza przepisy w życie na terytorium Prus Królewskich. Znane są $i$ inne przykłady, a wiele spraw wymaga szczegółowego zbadania.

${ }_{33}$ Por. E. Cieślak, Walki społeczno-polityczne $w$ Gdańsku w drugiej połowie XVII wieku - Interwencja Jana III Sobieskiego, Gdańsk 1962.

34 Niektórzy autorzy (zwłaszcza J. Gierowski) kładą nacisk na rolę Augusta II ok. $1720 \mathrm{r}$. i wiążą z problematyką centralizacji i przebieg represji związanych z tumultem toruńskim 1724 r.; por. J. Staszewski w recenzji z książki W. Gastparego o tumulcie toruńskim, „Odrodzenie i Reformacja”, XVIII (1973) 231-239. Dla ustroju Rzeczypospolitej nadal niedostatecznie przeanalizowano genezę i skutki decyzji z $1717 \mathrm{r}$.

${ }_{35}$ Dworska polityka obu Sasów, a zwłaszcza Brühla rodziła tu liczne napięcia.

36 Ideologia XVII wieku i jej piśmiennictwo są to kwestie do tej pory niemal nieznane. Por. w zasadzie jedyna próba monografii ogólnej, w swych sądach wielce dyskusyjna i nie wyczerpująca problematyki ,autonomizmu" i ideologii stanowej sensu stricto: T. Schieder, Deutscher Geist und ständische Freiheit im Weichsellande. Politische Ideen und politisches Schriftum in Westpreussen von der Lubliner Union bis zu den polnischen Teilungen (1569-1772 (93). Königsberg 1940, który na s. 51 podkreślił $\mathrm{z}$ dumą, iż $\mathrm{w}$ dobie kiedy szlachta w XVII w. nie myślała o prawach prowincji bronili ich tylko pisarze gdańscy od Reinholda Curickego poczynając. Nb. nie znał Schieder rkpsu dzieła E. K. Schrödera. 
4. Lata $1764-1772$ to okres burzliwy w dziejach Prus Królewskich: na reformy Czartoryskich odpowiedziała niezwykle agresywna i nie przebierająca w środkach kontrofensywa autonomistów. Ich częściowe sukcesy osiągnięte $\mathrm{w}$ oparciu o zagranicę były pyrrusowe: I rozbiór Polski wyrzucił na śmietnik historii obrońców swobód stanowych, które dawno już $\dot{z}_{i}$ zlikwidowali wszyscy potężni sąsiedzi polskiego państwa szlacheckiego ${ }^{37}$.

Jeżeli $\mathrm{w}$ naszych rozważaniach akcentowaliśmy stale globalny punkt widzenia, należy podkreślić, iż zagadnieniem szczególnym była tu umiejętność zachowania odrębnej pozycji przez wielkie miasta, a w pierwszym rzędzie przez Gdańsk. Należy więc pamiętać, iż nigdy nie można utożsamiać rzeczywistych i uzurpowanych praw Gdańska z prawami prowincji jako całości. Jeżeli co do Torunia i Elbląga sprawa jest stosunkowo prosta i polega na tym, iż miasta te w oparciu o posiadane przywileje, jak i ustrój wewnętrzny Prus Królewskich, zdołały zachować swobody i pozycję polityczną, jakiej nie utrzymały na przykład Kraków czy Lwów ${ }^{38}$, to co do Gdańska mamy do czynienia z sytuacją odmienną, niedostatecznie dotąd zbadaną, a w opracowaniach erudytów niemieckich z reguły fałszywie przedstawianą ${ }^{39}$. Ostatnie badania S. Matysika i E. Cieślaka pozwalają na bliskie już systematyczne rozważenie całoksz.tałtu, przy czym naszym zdaniem szczególną także uwagę należy poświęcić krytycznej analizie gdańskiej literatury XVII-XVIII w. ${ }^{40}$, która tak przemożnie ciążyła na wszystkich niemal opracowaniach okresu przed r. $1945^{41}$. Nie wchodząc w niezwykle zresztą interesujące dzieje metod, jakimi Gdańsk bronił uporczywie swych interesów ${ }^{42}$, jak i sy-

${ }^{3 \pi}$ O ogólnoeuropejskiej fali aspiracji stanowych ok. połowy XVIII w. (Szwecja, Francja, Belgia itd.) por. R. R. Palmer, The Age of the Democratic Revolution. A political History of Europe and America, 1760-1800, I, Princenton 1959, zwłaszcza s. 27 n., 55 n., 86 n., 341 n.

${ }_{33}$ Co do Torunia por. moje uwagi, $Z$ problematyki narodowościowej $i$ politycznej osiemnastowiecznego Torunia, „Spraw. TNT”, 21, 1967, (p. 1969).

${ }_{39}$ Wyjątkiem był tu nastawiony przeciw Radzie Miejskiej gdańszczanin E. K. Schröder; por. o nim S. Matysik, Eliasz Konstanty Schröder gdańsłi prawnik $i$ sekrct rrz królewski z XVII w. Życie $i$ dzieło, CPH, VI, 1954, 1. Był on autorem dzieła Ius Publicum Dantiscanum (uk. 1657). Dziękując Prof. K. Górskiemu za udostępnienie mi maszynopisu odpisu rkpsu chciałbym wyrazić żal, iż projektowane (K. Górski - S. Matysik) wydanie tego ważkiego rkpsu nie zostało do tej pory zrealizowane.

40 Dla XVII w. należy opracować poglądy Curickego, dla XVIII w. m. in. pisma G. Wernsdorfa szczególnie aktywnego w walce o prawa dysydentów i interpretatora traktatu oliwskiego z 1660 r. (co stanowi samo temat dla siebie), por. także liczne mniejsze druki polemiczne z XVIII w. w Ks. M. Toruń sygn. B fol. 124.

¿1 Por. rozprawy J. Kaufmanna, P. Simsona, O. Günthera i in.

42 M. in. Rada Miejska otaczała troskliwie tajemnicą wszelkie sprawy związane z uprawnieniami miasta. Warto wskazać przykłady stosowanych taktyk. I tak Gdańsk zawsze oficjalnie uważał, iż nie podlega konstytucjom sejmowym, że Prusy Kr. a Korona to dwa odrębne kraje, jednakże nie protestował, kiedy sejmy nobilitowały gdańszczan (o czym Lengnich milczy), ani kiedy konstytucje sejmowe były 
tuacji, które w ramach ustroju Rzeczypospolitej Obojga Narodów ułatwiały $\mathrm{mu}$ owe działania ${ }^{43}$, należy podkreślić, iż podstawą efektywnej znacznej faktycznej (a nie prawnej) niezależności Gdańska w ramach państwa polskiego była jego potęga ekonomiczna, utrzymanie a także rozszerzenie per fas et nefas korzystnych przywilejów handlowych i ekonomicznych, których polityczna obrona prowadziła do niczym niemaskowanych uzurpacji praw zwierzchnich królów i Rzeczypospolitej w Gdańsku ${ }^{44}$. Skuteczność tych działań nic nie miała w ostatniej instancji wspólnego z problemami prawa, rolą Gdańska w Hanzie czy też domniemanymi, a nigdy Gdańskowi nie przyznanymi prawami w zakresie prawa międzynarodowego, lecz opierała się na potędze ekonomicznej, dogodnym położeniu geopolitycznym opartym także o władztwo terytorialne miasta, na niewielkim ale ważnym terytorium wokół samego miasta. Tak więc pozycję Gdańska w XVII-XVIII w. oceniać należy w kategoriach polityki a nie ustroju ${ }^{45}$, porównywać $\mathrm{z}$ wichrzeniami magnackimi, $\mathrm{z}$ polityką quasi samodzielną takiego Janusza Radziwiłła, Jerzego Lubomirskiego, z rządami Sapiechów na Litwie u progu XVIII w. ${ }^{46}$.

Przechodzimy do spraw XVIII w. Dla okresu do r. 1764 zaakcentować należy następujące elementy obrazu:

1. Na płaszczyźnie stanu szlacheckiego dochodzi do dalszej unifikacji życia politycznego i poglądów z sytuacjami charakterystycznymi dla pozostałych terytoriów Rzeczypospolitej. Nawet pewne zadrażnienia powodowane bądź przejawami wystąpień kontrreformacyjnych, bądź polityką Augusta II i Augusta III nie zmieniają tego ogólnego twierdzenia ${ }^{47}$.

dla Gdańska korzystne, bądź spór nie na czasie; por. dotąd szczegółowo niezanalizowane ustawy w VL, III, 580, III, 680, III 939, IV, 104, VI, 254. Nie tylko wchodziły w życie w Prusach konstytucje ogólne dla państwa ale i specjalnie wydawane dla Prus Kr. bądź ich miast, por. VL, II, 1270, III, 960, 964, IV, 135; por. także interesujący przykład J. Małecki, Przyczynek do kwestii prawno-politycznego stosunku Gdańska do Rzeczypospolitej, ZH, XXXII, 1967, 3.

${ }_{43}$ Dotąd nie rozwinięto szerzej kwestii (poruszonej w pracach E. Cieślaka) roli interesów własnych królów polskich w Gdańsku, ich „dogadywania się” kosztem uprawnień a za doraźne spore korzyści finansowe z władzami miasta. Tylko August III za swe interwencje gdańskie uzyskał ok. 800 tys. złotych, które wpływały do jego kasy, a nie do skarbu Rzeczypospolitej. Ten fakt wiele tłumaczy z polityki królów od Batorego po Augusta III.

${ }_{44}$ S. Matysik (w pracy zbiorowej Gdańsk. Jego dzieje..., 39) podkreślił, iż Gdańsk nigdy nie wypełnił swych obowiązków wynikających z przywilejów kazimierzowskich, czyli, że gdańszczanie pogwałcili tę umowę stron, na którą wiele razy następnie się powoływali. Nie ulega wątpliwości, iż to dopiero od $1717 \mathrm{r}$. doszło do pewnego ograniczenia uzurpacji.

45 Por. E. Cieślak, Przywileje Gdańska z okresu wojny 13-letniej na tle przywilejów niektórych miast battyckich, CPH, VI, 1954, 1.

$46 \mathrm{Nb}$. to właśnie magnaci (w przeciwieństwie do szlachty) wielokrotnie - i nie bez korzyści - popierali w XVII-XVIII w. Gdańsk; por. W. Czapliński, Problem Gdańska w czasach Rzeczypospolitej szlacheckiej, "Przegląd Historyczny", XLIII (1952) 284-285.

${ }_{47}$ W cyt. zarysie W. Odyńca szlachta Prus Kr. nie została szerzej potraktowana. Istnieje tu pilna potrzeba badań dla okresu XVII-XVIII w. 
2. W okresie po zakończeniu Wojny Północnej aż po schyłek rządów Augusta III życie polityczne prowincji przeżywa głęboki regres. Można powiedzieć, iż jedynie lata bezkrólewia po śmierci Augusta II w związku z mocnym zaangażowaniem się Gdańska i innych czynników po stronie Leszczyńskiego wprowadziły Prusy Królewskie na czas krótki do czynnej polityki krajowej. Od 1734 do 1763 r. wydarzenia w Prusach Królewskich charakteryzują się głównie partykularnymi sporami politycznymi koterii magnackich, co prowadziło do okresowego całkowitego paraliżu życia sejmikowego pruskiego: sejmik generalny pruski nie zebrał się ani razu od 1713 do 1728 a następnie systematycznie był od 1735 r. zrywany.

3. O aktywnej i konsekwentnej polityce Warszawy w kierunku centralizacji państwa trudno by $\mathrm{w}$ tym okresie mówić: Rzeczypospolita do takiej polityki reform w dobie panowania zasady liberum veto nie była zdolna, a wszelkie próby wzmocnienia władzy królewskiej napotkały na opór i obawy nie tylko i może nie tyle w Prusach Królewskich, co generalnie wśród rzesz szlacheckich żyjących strachem przed absolutum dominium.

4. Istniało niewątpliwie za to dążenie kolejnych władców do wzmocnienia własnych prerogatyw w Prusach, bądź po prostu uzyskania tylko dodatkowych korzyści finansowych. W tej mierze wymienić można jako ważniejsze fakty wykorzystywane przez politykę dworu: August II i August III wielokrotnie, mimo protestów, łamali zasadę indygenatu pruskiego z reguły na rzecz królewskich faworytów ${ }^{48}$. Poważniejsza ingerencja władz $\mathrm{w}$ sprawy miast wiązała się z reguły $\mathrm{z}$ konkretnymi wydarzeniami politycznymi. W $1724 \mathrm{r}$. w związku z tzw. tumultem toruńskim król poprzez działania centralnych władz sądowych przeprowadził nie tylko szereg decyzji represyjnych, ale i poważne zmiany w ustroju Torunia 49. Ingerencja Augusta III w sprawy gdańskie miała charakter znacznie szerszy i przyniosła poważne sukcesy 50 .

5. Ostatecznie i nie bez wpływu wspomnianych wyżej wydarzeń toruńskich i gdańskich w I poł. XVIII w. jedynie owe miasta pozostały obrońcami szerzej rozumianych niż ówczesna rzeczywistość życia politycznego i prawnego Prus Królewskich tzw. swobód krajowych. I rzeczą może paradoksalną ale i naturalną jest fakt, iż tzw. odrodzenie aspiracji autonomicznych Prus Królewskich, które przyniosą zwłaszcza lata trzydzieste i czterdzieste XVIII w., było początkowo i nade wszystko nie tyle faktem życia politycznego a jedynie dziełem literatury naukowej i publicystycznej. Jeżeli żywe inspiracje szły tu, tak jak i dawniej, od gdań-

48 U progu rządów Stanisława Augusta toczył się nadal zacięty spór wokó1 sprawy nadania w $1758 \mathrm{r}$. urzędu nieindygenie Pawłowi Mostowskiemu.

${ }_{49}$ Por. S. Salmonowicz, dz. cyt., passim oraz tegoż, O problematyce politycznej $i$ prawnej tzw. Tumultu Toruńskiego z 1724 r., CPH, XXIV, 1972, 1.

50 Por. E. Cieślak, Konflikty polityczne $i$ społeczne $w$ Gdańsku $w$ połowie XVIII w. Sojusz pospólstwa z dworem królewskim, Wrocław-Warszawa 1972. 
skiego patrycjatu, należy także sądzić, iż duże znaczenie praktyczne miał sam rozwój zainteresowań przeszłością ziemi rodzinnej, rozwój jǚ od końca XVII w. studiów erudycyjnych ${ }^{51}$, których ukoronowaniem była wielka działalność Lengnicha. Stykając się z perspektywy XVIII w. z dokumentami minionych wieków i nadając im nowożytną treść (niekiedy już refleks haseł oświeceniowych ad hoc przystosowywanych do życia stanowego Prus) a wreszcie i tendencyjne interpretacje stwarzali w ten sposób Lengnich, jego prekursorzy i naśladowcy, mocne podstawy dla ożywienia owych już zamarłych w świadomości społecznej aspiracji, które można by określać niezbyt ściśle roszczeniami autonomicznymi 5 ? Tak więc postać Lengnicha, do dziś jakże mało znanego prawnika i historyka, ale i zarazem wytrawnego polityka, obroncy uprzywilejowanych rządów patrycjatu gdańskiego, wysuwa się tu na czoło ${ }^{53}$.

Przypomnijmy krótko, iż gdańszczanin Gotfryd Lengnich (16891774) był wychowankiem Gdańska i Halle (wpływy Ch. Thomasiusa, Ch. Wolffa) związanym $z$ tzw. szkołą prawa publicznego w Halle, J. P. Ludewigiem i M. H. Gundlingiem ${ }^{54}$. Jako prawnik i historyk zapisał się trwale $\mathrm{w}$ dziejach nauki Oświecenia w Polsce, jednakże w środowisku gdańskim pozostawał całe życie związany z interesami patrycjatu, choć umiejętności dyplomatyczne pozwalały mu na unikanie ostrych konfliktów w trudnych sytuacjach ${ }^{55}$. Jego rola dla dziejów myśli politycznej i prawnej w Prusach Królewskich XVIII w. była ogromna, do dziś w pełni niedoceniona i niezbadana ${ }^{56}$, a służbie głoszonych przez siebie poglądów i tez podporządkował Lengnich w dużej mierze całą swą niemal twórczość historyczną ${ }^{57}$. Dla interesującego nas problemu

51 Por. S. Salmonowicz, W kręgu toruńskich erudytów osiemnastego wieku, w: Księga pamiatkowa 400-lecia toruńskiego gimnazjum akademickiego, I, Toruń 1972.

52 Rola polityczna w XVIII w. grupy tzw. litterati w Gdańsku i w Toruniu (na co zwrócil uwagę E. Cieślak) nie pozostawała bez wpływu na kierunek dążeń w polityce i ideologii tego okresu.

53 Por. moje zestawienia $w$ biogramie G. Lengnicha, PSB, XVII, 1, z. 72, s. 46-49. Praca S. Sosina, Autonomia Prus Królewskich w ujęciu G. Lengnicha, „Gdańskie Zeszyty Humanistyczne”, I, (1958), jest już dziś absolutnie niewystarczająca.

${ }_{54}$ Już T. Schieder w recenzji z pracy Kurdybachy, Altpreussische Forschungen, $15,1938,1$, s. 132 , wiązał autonomiczne koncepcje Lengnicha z wpływami Halle; por. H. Lemke, Die Brüder Załuski und ihre Beziehungen zu Gelehrten in Deutschland und Danzig, Berlin 1958, 177-178, ogólnie moje uwagi, Krystian Bogumił Steiner (1746-1814) toruński prawnik $i$ historyk, Toruń 1962, 50-57.

55 Jeżeli intelektualnie był Lengnich ok. 1740 r. bliski kształtującym się założeniom reformatorskim Czartoryskich, jeżeli przez długie lata pozostawał w dobrych stosunkach $\mathrm{z}$ dworem, to tak jak r. 1750 ukazal jego prawdziwe oblicze stronnika patrycjatu, tak lata następne postawiły go na szańcach walki z reformami w imię interesów Gdańska.

${ }_{56}$ Najobszerniej poglądami Lengnicha zajął się dotąd T. Schieder w swej cytowanej książce s. 134-172. Rzecz wymaga nowego studium.

${ }_{5 \pi} \mathrm{Z}$ historyków polskich najwięcej dotąd uwagi poświęcił mu W. Konopczyński, por. zwłaszcza Spór o wrota morza Battyckiego w: Mrok i świt, Warszawa 1911. 
tzw. restauracji dążeń autonomicznych w Prusach kamieniami milowymi były właśnie dzieła Lengnicha, a to nade wszystko trzy wielkie opracowania: Geschichte der preussischen Lande Königlich-Polnischen Antheils seit dem Jahre 1526 (9 tomów w 1. 1722-1755), Siaats-Recht des Polnischen Preussen (1760) i niepublikowane za życia autora dzieło pt. Ius publicum civitatis Gedanensis oder der Stadt Danzig Verfassung und Rechte (powstałe ok. 1760) ${ }^{58}$. Można powiedzieć iż nie tylko współcześni ale i następcy — zawodowi już historycy — z reguły będą czerpać z dzieł Lengnicha informacje o dziejach politycznych, ustroju i prawie Prus Królewskich. Stąd też należy krótko je ocenić - w świetle naszej dzisiejszej wiedzy — choć, rzecz jasna, odczuwać się wielce daje brak szczegółowych studiów nad metodami pracy, sposobami formułowania wniosków i innymi elementami warsztatu naukowego Lengnicha ${ }^{59}$. „Pruski Tacyt" podejmując wieloletnie studia w pilnie strzeżonym archiwum Rady gdańskiej złożył uroczystą przysięgę, iż niczego publicznie nie ujawni, co by na szkodę praw miasta mogło służyć. Przyznać trzeba, iż przysięgi tej dotrzymał, choć to nieraz kolidowało z jego historycznym powołaniem ${ }^{60}$.

Monumentalna Geschichte der preussischen Lande... zbudowana została w oparciu o ogromny, do dziś głównie niedrukowany materiał źródłowy, czerpany bezpośrednio z archiwum gdańskiego. Wartość dzieła określają także aneksy, w których zawarte zostały in extenso liczne dokumenty stanów pruskich i inne materiały źródłowe. Jest to nade wszystko historia polityczno-ustrojowa Prus Królewskich widziana przez pryzmat partykularnych roszczeń i niewolna od wyraźnej nostalgii za średniowiecznymi swobodami stanowymi Prus Królewskich, choć autor wielokrotnie swoją ,restaurację" autonomizmu usiłował podbudowywać echami oświeceniowych prawnonaturalnych koncepcji ${ }^{61}$. W swych interpretacjach tendencyjny ${ }^{62}$, a $w$ informacjach niekiedy świadomie nieścisły, widział Lengnich okres rządów saskich jako niemal zakończenie długiego procesu unifikacji Prus Królewskich z Koroną i z całych sił walczył z tą koncepcją. Dzieła następne Lengnicha zaostrzyły jeszcze jego ogólne tezy i swego rodzaju program pozytywny: maksymalnej

ss Opublikował to dzieło ze wstępem O. Günther w $1900 \mathrm{r}$.

59 Wielokrotnie już wskazywano na tendencyjność i przemilczanie niewygodnych faktów przez Lengnicha (K. Górski, E. Cieślak, Ł. Kurdybacha, J. Małłek), którego przecież ogromna erudycja i bogactwo wykorzystywanych źródeł czas długi chronily przed jakimikolwiek zarzutami.

${ }_{60}$ H. Lemke, dz. cyt., 177, podkreśla, iż dla Lengnicha podobnie jak i jego mistrzów z Halle ,die Geschichte war das Arsenal, dem man brauchbare Waffen entnahm, die auf dem Felde der Politik Verwendung finden konnten".

61 T. Schieder, dz. cyt., 138; E. Winter, Frühaufklärung. Der Kampf gegen den Konfessionalismus in Mittel- und Osteuropa $u$. die deutsch-slawische Begegnung, Berlin 1966, 237-238.

62 O tym nawet T. Schieder, dz. cyt., 143-144. 
rozbudowy i utrzymania swobód Prus Królewskich. Najdalej w tym kierunku poszedł autor $\mathrm{w}$ ostatnim $\mathrm{z}$ wielkich dzieł o prawie publicznym Gdańska, które przezorna Rada Miejska wolała pozostawić w rękopisie. W swych dziełach, wychodząc stale z pozycji "stanu obowiązującego" i reprezentując swoisty legalizm myślenia, nie był przecież $w$ stanie Lengnich wielokrotnie uniknąc przyznania, iż jego tezy były raczej postulatem niż praktyką czasów współczesnych ${ }^{63}$.

Wydaje się, iż nie jesteśmy $\mathrm{w}$ tej chwili w stanie odpowiedzieć w sposób definitywny i pogłębiony, jakie były przyczyny silnego odrodzenia aspiracji autonomicznych w 1 poł. XVIII w. Studium historii politycznej Prus Królewskich, zwłaszcza lat 1735-1763 z jednej strony, a badania dziejów piśmiennictwa ${ }^{64}$ i opinii publicznej Prus Królewskich i czynników ją kształtujących z drugiej, wiele by tu wyjaśniły. Sądzę, iż obok przyczyn ogólnych, takich jak wpływ postępującej anarchizacji życia politycznego w Rzeczypospolitej, oraz wzrostu obaw o swobody wyznaniowe, duże znaczenie miały zapewne nadzieje Gdańska na korzyści gospodarcze z odrodzenia ekonomicznego kraju, które — wraz z interwencjami Augusta II i Augusta III zaostrzyły walkę miast o utrzymanie ich uprzywilejowanej pozycji, a nawet jej umocnienie. Stąd liczne spory tych lat, które znalazły wyraz $\mathrm{w}$ polemikach ${ }^{65}$, a prowadzone były niemal wyłącznie przez przedstawicieli Gdańska i Torunia ${ }^{66}$. Być może, iż na niekorzyść władz centralnych działał także refleks niechęci wobec absolutyzmu oparty na obserwacji stosunków w państwie brandenburskopruskim, refleks, który odnoszony do sytuacji ówczesnej w Rzeczypospolitej świadczył nie tylko o krótkowzroczności owych kół mieszczaństwa pomorskiego, ale i o podkreślonym już przeze mnie w swoim czasie swoistym poglądzie (podzielanym przez zacofaną szlachtę) o trwałości istnienia Rzeczypospolitej, co paradoksalnie pozwalało właśnie z tą Rzeczypospolitą walczyć, odmawiać jej uprawnień, które królowie pruscy po 1772 r. przejmą bezdyskusyjnie, żadnych rozmów z miejscowymi siłami nie prowadząc i żadnych argumentów prawnych nie dyskutując.

63 Por. G. Lengnich, Staats-Recht des Polnischen Preussen..., zwłaszcza § 89-90, 108, 109. Nb. I wydanie dzieła po łacinie to rok 1758.

$64 \mathrm{Na}$ zbadanie czekają m. in. twórczość rektora szkoły elbląskiej J. D. Seylera, autora podręcznika pt. Das itzige Polnische und Polnisch-Preussische Staatsrecht, WAP Gdańsk, Arch. m. Elbląga, E 4, fol. 2-35, liczne polemiki tego okresu jak polemika Zygmunta J. Rybickiego z syndykiem gdańskim J. A. Rosenbergiem, Estreicher, XXVI, 507-8.

65 Por. klocek Ks. M. w Toruniu E $4^{\circ} 453$, z wystąpień antygdańskich por. w Ks. M. w Toruniu tekst anonimowy pt. Censura civilis, Famosis Libelli Intitulati Responsio Civitatis Gedanensis..., 1713, gwałtownie antygdański. Por. P. v. Schröter, Gründlicher Beewis dass das Westliche oder, so genannte Polnische Preussen ein Gross-Herzogthum sei..., Halle-Leipzig 1755, B. Czart. 12313 I.

66 Por. $\mathrm{m}$. in. Immunitas Civitatum Prussiae a Iurisdictione Iudiciorum Tribunalitiorum Regni Poloniae..., anonimowo 1718, Ks. M. w Toruniu. 
Opracowana świeżo w ośrodku toruńskim rozprawa Jerzego Dygdały ${ }^{67}$ w sposób szczegółowy i kompleksowy przedstawia politykę władz miejskich Torunia wobec władz centralnych w latach 1764-1772 i choć nie stanowi całościowego ujęcia politycznej strony walki o utrzymanie względnie nawet rozszerzenie partykularnych swobód, przynosi w tym względzie wiele nowych ustaleń. Warto zaakcentować zasadnicze dla dalszych wywodów tezy autora: Toruń i Gdańsk były - przy chwiejnym i biernym stanowisku szlachty Prus Królewskich - rzecznikami i inspiratorami tego ruchu ${ }^{68}$, który w konkretnych warunkach lat 1764-1772 prowadził do zdecydowanego oporu przeciw wszelkim reformom państwa, a w konsekwencji, w drodze oparcia się o obce potęgi, do dysydenckiej konfederacji toruńskiej 1767, do faktycznego działania na równi z reakcyjną Konfederacją Radomską przeciw próbom odrodzenia państwa i narodu. Rola Gdańska tych lat jest mniej w tej chwili znana i można zaryzykować pogląd, że to właśnie Toruń, głównie dzięki rzutkiej, wszechstronnej i agresywnej działalności w Warszawie swego rezydenta Samuela Lutra Gereta, odegrał w interesującej nas kwestii rolę zasadniczą. Dodajmy, iż jeżeli nadal w polemikach tych lat występował $z$ nowymi publikacjami stary Lengnich ${ }^{69}$, a na odcinku polemik wyznaniowych (pośrednio zawsze powiązanych z problemem swobód Prus Królewskich) występowali liczni autorzy 70, to właśnie toruńskiemu politykowi zawdzięczamy opracowanie zbioru tekstów, który można określić jako maksymalistyczny wyraz programu autonomistów w XVIII w. Przed przejściem do omówienia tej całkowicie dotąd zapomnianej publikacji należy nakreślić sylwetkę jej autora, człowieka, który niewątpliwie był najwybitniejszym politykiem reprezentującym dawniejszy, mocno jeszcze akademicki, program polityczny Lengnicha. S. L. Geret $(1730-1797)^{71}$ syn pastora toruńskiego należał do czołowych intelektualistów toruńskich swej epoki i po studiach zagranicznych, działalności uniwersyteckiej w Wittenberdze oraz efemerycznej profesurze szkoły toruńskiej poświęcił się karierze polityka miejskiego, przy czym zasadnicze znaczenie miała jego działalność jako długoletniego rezydenta Torunia na dworze warszawskim, kiedy to w pierwszych latach rządów Stanisława Augusta usiłował on poprzez bezpośrednie związki z ambasadorem rosyjskim wpływać efektywnie na bieg spraw publicznych w Rzeczypospolitej, a w szcze-

67 Por. przypis 7.

6 8 Cy bez sprawy Mostowskiego uchwały grudziądzkie 7 IX 1767 doszłyby do skutku?

69 Już w $1764 \mathrm{r}$. ogłosił dwa pisma w obronie zagrożonych swobód.

$\therefore$ Por. zwłaszcza publikacje G. Wernsdorffa, Ks. M. Klocek E 82308.

"1 Por. H. Piskorska, PSB, VII, s. 391-393, bibliografia prac J. F. Goldbeck, Literarische Nachrichten von Preussen, Berlin 1781-3, I, s. 37-39, II, s. 17; S. Salmonowicz, Toruńskie gimnazjum akademickie (1681-1817), Poznań 1973, 252-261, $324-328,337$. 
gólności w kierunku po pierwsze obrony interesów Prus Królewskich (mianowicie interesów wielkiego patrycjatu Torunia i Gdańska), a po drugie obrony interesów dysydentów w Polsce. Należy podkreślić, iż byl Geret wybitnym prawnikiem i znawcą historii, a jego wspaniała biblioteka stanowiła podstawę do jego licznych przedsięwzięć pisarskich oraz inicjatyw na polu czasopiśmiennictwa ${ }^{72}$.

W zbiorach Biblioteki UAM w Poznaniu zachował się unikat: zapomniana publikacja Gereta wydana anonimowo w 1774 r. w Mitawie, jeżeli wierzyć informacji na stronie tytułowej. Jest to zbiór tekstów samoistnych ogłoszonych pod ogólnym następującym tytułem: Die aus den Gräbern durchbringende Stimme derer vor zwey hundert fünfzig Jahren verstorbenen wahren und ächten Preussen zur Erweckung und Besserung an die jetzt lebenden zu Polen ausgearteten Preussen, gehöret in verschiedenen alten Schlössern und Klöstern in Preussen. Autorstwo Gereta, który z reguły swe druki polemiczne publikował anonimowo, było już uznane w XVIII w. ( $\mathrm{m}$. in. Goldbeck i inne zestawienia bibliograficzne) i przyjęte także przez K. Estreichera ${ }^{73}$. Geret zresztą występował pod przejrzystym dość przykryciem, skoro po pierwsze $\mathrm{w}$ przedmowie do dzieła wyraźnie dał do zrozumienia, iż jest toruńczykiem (Aus Landeck-Lande-Ecke), ogłosił w ramach omawianego zbioru swój znany memoriał z 1765 r. przeciw generalnemu cłu, a wreszcie w posłowiu wyjaśniającym opóźnienie się publikacji wspomniał wyraźnie inną swą publikację (Erwägungen...). Niezupełnie za to jasne są okoliczności towarzyszące publikacji, która zgodnie $\mathrm{z}$ datą $\mathrm{w}$ zakończeniu części wstępnej była przygotowana do druku już 1 listopada 1771 a zgodnie z kartą tytułową ukazała się dopiero w $1774 \mathrm{r}$. Na ostatniej stronie zbioru liczącego stron 152 czytamy dwa wyjaśnienia tej kwestii: Schluss-Erinnerung datowana na 26 VIII 1772 stwierdza, iż nieodpowiedzialność pewnych osób (drukarza?) spowodowała opóźnienie druku publikacji, która przecież nadal jest aktualna, a Abermalige Nach-Erinnerung z 31 XII 1773 obciąża odpowiedzialnością za dalszą zwłokę brak bezpieczeństwa korespondencji oraz niesolidność innych osób ale - mimo już wkroczenia w okres porozbiorowy na terytorium dotychczasowych Prus Królewskich - Geret nadal uważa, iż zbiór jego może być wielce pożyteczny, bowiem mówi o dotychczasowym ustroju kraju i ,,[... theils von der Beschaffenheit der damit erfolgten Abtretung urtheilen und denen von solchem Lande übrig geblieben ihre Gerechtsame und Freyheiten würdiglich erhalten helfen zu können". Nim przejdziemy do rozważań o treści omawiañego zbioru, należy krótko podać, z jakich się części on składa:

72 O jego działalności redaktorsko-wydawniczej por. M. Dunajówna, Z dziejów toruńskiego czasopisma "Thornische Wöchentliche Nachrichten und Anzeigen" (1760-1772), Toruń 1960, passim.

73 K. Estreicher, XVII, 108. 
1. Z wstępu ogólnego mającego zarazem charakter pisma dedykacyjnego skierowanego do Ludwika (IV) Weihera w związku z jego sporem z koronnymi władzami skarbowymi ${ }^{74}$ (strony 1-44).

2. Tekstu pt. Geschichte und Beweise von der Staats-Verfassung, Regierungs-Form, Rechten und Freyheiten der Lande Preussen, eine StaatsSchrift, öfentlich abgegeben im Jahr 1765 bey Gelegenheit, da die Repubiik Polen kurz vorher den errichteten General-Zoll auch über die Lande Preussen zu erstrecken sich angemasset hatte (strony 45-76).

3. Tekstu Gereta z 1767 r. dowodzącego, iż państwo polsko-litewskie to tylko luźna unia personalna różnych terytoriów w pełni niemal niezależnych, a wśród tych terytoriów oczywiście szczególną pozycję mają Prusy Królewskie ${ }^{75}$ (strony 77-108).

4. Projektu całkowitego uniezależnienia sądownictwa Prus Królewskich od Korony z 1769 r. ${ }^{76}$ (strony 109-124).

5. Tekstu pt. Beredungen zwischen etlichen Vornehmen von Lande und Städten Als zu Erhaltung unter denen Edlen von Lande und Städten die alte Gleiheit unter denselbigen, worauf diese Lande gegründet seyn, bey Verschiedenheit der Würden, Aemter und Bedienungen bestahen mochte [...] (strony 125-132).

6. I wreszcie z przedruku tekstu wyroku sejmowego z 1643 r. o prawie mieszczan w Prusach Królewskich trzymania i nabywania dóbr ziemskich (królewszczyzn), zaopatrzonego komentarzem Gereta ${ }^{77}$ (strony 135-141).

Uwagi ogólne o zbiorze Gereta zacznijmy od stwierdzenia, iz mimo pewnego wysiłku w kierunku zgromadzenia bogatych materiałów historycznych i prawnych nieraz nieznanych (pozycja 6) generalnie nie wyszedł on poza krąg ustaleń Lengnicha. Mimo przecież licznych autentycznych załączników, dołączonych ekscerptów historycznych i innych dowodów uczoności, zebrane w zbiorze Gereta teksty są nade wszystko broszurami politycznymi, a nie traktatami prawniczymi czy tez historycznymi. Swym ostrym, polemicznym, wielokrotnie wręcz agresywnym

it Herrn Ludwigs von Weyher, [...] Sicherheit für Polen, wegen erlaubter Errichtung eines Berliner-Lotterie-Contoirs in Langfuhr, in einen Sendschreiben [...] vom 1-sten November 1771.

75 ,Beweis dass die Lande Preussen nicht unter der Republick Polen sondern unter dem Könige von Polen sind und dass Ermeland, Culmigerien, Pomesanicn und Pommern eine eben solche Republick... wie Gross-Polen, Klein-Polen, Reussen und Lithauen..., gefuhrt zur Zeit der grossen Delegation vom Reichstage des Jahrs 1767 in Warschau".

i6 "Gedanken und Entwurf von einem wiederherzustellenden eignen Tribunal für die Lende Prcussen [...]", 1769.

i7 . Rechts-Urtheil über die denen Städtischen so wohl als denen von Lande leich gut zustehende Befugniss und Gerechtsamen, Königliche Gütor sich zu verleilen suchen $[\ldots]^{\prime}$ 
tonem ${ }^{78}$ wyraźnie odbiega od tych zalet naukowej formy wywodów Lengnicha, które prawnikowi gdańskiemu tyle sukcesów przynoszą po dzień dzisiejszy. Dodajmy, iż ów obiektywizm, wielokrotnie tylko pozorny, i olimpijski spokój Lengnicha doprowadzony w wywodach Gereta bez obsłonek do rangi programu politycznego pozbawionego (mimo pewnych usiłowań) ochronnej szaty naukowej, pozwala na łatwiejszą ocenę wartości tez Lengnicha i stopnia obiektywizmu jego wywodów, a nade wszystko celów, do których rzeczywiście dąży syndyk gdański, a za którym poszedł dalej niż ktokolwiek inny (ponad zapewne intencje Lengnicha) toruński polityk i publicysta. Sądzić należy, iż różnice wykreślają tu nie tylko burzliwe przemiany lat $1764-1772$, ale i właściwy Geretowi temperament polityka ambitnego i bojowego, nadmiernie zreszta $\mathrm{w}$ tych latach przeceniającego swoją rolę $\mathrm{w}$ Warszawie $\mathrm{u}$ boku ambasadora rosyjskiego ${ }^{79}$. Jeżeli nie ulega wątpliwości, iż głównym a paradoksalnym celem Gereta głoszonym w zbiorze jest pełna restauracja swobód krajowych - takich, jakie według jego mniemania przysługiwały Prusom Królewskim w XV w., to zarazem broni on status quo przeciw wszelkim unifikacyjnym reformom wprowadzanym pod rządami Stanisława Augusta. Niekiedy też występuje Geret expressis verbis z propozycjami zmian, uwagami de lege ferenda (jak co do utworzenia nowego trybunału tylko dla Prus Królewskich), jednakże są to zawsze propozycje stanowiące wyraz dążeń partykularnych i interesów nie tyle całej prowincji, co niemal wyłącznie tradycyjnego bogatego patrycjatu, który pragnął nie tylko zachowania dotychczasowej pozycji, ale i jej umocnienia zarówno wobec szlachty swej prowincji, co i wobec władz centralnych. Lektura publikacji Gereta jest dość nużąca, bowiem wielokrotnie powtarzają się w owych układanych odrębnie tekstach te same wątki i stwierdzenia, a całości nie brak wielu cech typowych dla pism procesowych tej epoki. Niektóre zresztą twierdzenia autor dobitnie powtarza także i ze względów propagandowych.

Co do metody i sposobu prowadzenia dowodów na przytaczane twierdzenia zauważyć należy, iż autor wielokrotnie popadał w sprzecznośc1, a prawne podstawy jego twierdzeń są niekiedy niezwykle wątłe. Przez całość zbioru stale powraca jako leitmotiv stwierdzenie, iż należy „Preussens wahre Verfassung wieder her zu stellen”. Tak więc z jednej strony Geret nie neguje, iż jego daleko idące twierdzenia nie mają pokrycia w rzeczywistości, a z drugiej dowodzi, iż obecny stan rzeczy jako zły i bezprawny należy zmienić - oczywiście na rzecz aspiracji stanowych Prus Królewskich. Równocześnie przecież, zwłaszcza tam, gdzie idzie

78 Przykładowo na s. 93: „Auf allen Seiten siehet man also Ungerechtigkeit, Aufhebung der Pacten, und der Freyheit, Unterdrückung und Herrschsucht!".

;9 $O$ tej roli Gereta pisze obszernie J. Dygdala, dz. cyt., passim. 
o prawa miast z Gdańskiem na czele, nie uchyla się autor od głoszenia poglądu, iż miasta swe uprawnienia „od niepamiętnych czasów” sprawują i powinny one być $w$ nich zachowane. Tak więc gdy jest to dla autora dogodne, broni on status quo względnie go atakuje. Bardzo wyraziście, mimo licznych taktycznych niedomówień, rysuje się w wywodach Gereta pogląd, iż to prowincja pruska sama wielokrotnie swe prawa zaniedbała, z nich zrezygnowała, odrębności nie broniła. Stąd i jego liczne ataki i wyrzuty pod adresem szlachty polskiej, która jego zdaniem w przeciwieństwie do miast nie broniła praw prowincji. Na s. 8 posunął się Geret $\mathrm{w}$ ataku na współczesne mu wystąpienia szlachty pruskiej, popierające procesy unifikacyjne, do żądania karania jej jako zdrajców, a na s. 113, wracając do sprawy dobrowolnego poddania się szlachty pruskiej Trybunałowi Koronnemu, tak pisał:

„Und dieser Schritt der Ritterschaft mit Annehmung des KronTribunals ist um so viel mehr zu verabscheuen, je unerhörter es ist, dass ein Theil einer Provinz, ohne Einstimmung des andern, in Sachen welche die Haupt-Verfassung betreffen, eigenmächtig solche erstauende Veränderung unternimmt, wie die ist, sein eigen Tribunal zu verlassen, und sich an ein fremdes zu wenden".

Pisywane w różnym czasie, ale w tym samym duchu, teksty Gereta opierały się ogólnie na fundamentalnej tezie (głoszonej już przez Lengnicha), iż Prusy Królewskie stanowią samodzielny organizm państwowy, związany jedynie unią personalną z Koroną, a podlegający w konsekwencji tylko władzy króla, a nie władzy centralnych organów Korony. Zdaniem Gereta stany pruskie stanowią na równi samodzielne ciało co i Korona i Litwa. Wychodząc z tych założeń Geret - wbrew n.b. licznym notoryjnym faktom, których był świadom ${ }^{80}$ - odrzucał w ogóle możliwość ingerencji administracyjnych bądź sądowych organów Korony na terytorium Prus Królewskich, stacjonowania tamże wojsk koronnych, podejmowania obowiązujących także w Prusach decyzji skarbowych, celnych itd. Wysuwając te tak daleko idące twierdzenia w swym piśmie do Ludwika Weihera (część I zbioru) nawiązywał stale do ogólnikowego tenoru przywilejów piętnastowiecznych, odrzucając globalnie sytuacje prawne, które określiły rzeczywisty stan prawny ustroju Prus Królewskich od $1569 \mathrm{r}$. Celem historyka nie jest podejmowanie polemik z poglądami minionych epok, lecz ich wyjaśnianie, jednakże lektura owych wywodów, dla których konkretnym punktem wyjścia była bezprawna zdaniem Gereta - ingerencja nowoutworzonej koronnej komisji skarbu w działania Weihera, potwierdza raz jeszcze (widoczną także i u Lengnicha) tendencję obrońców ustroju stanowego żarliwej obrony, posu-

80 Zwłaszcza dla epoki Augusta III. 
niętej do absurdu w dobie XVIII w., uprzywilejowanych swych pozycji. Z wywodów Lengnicha, a zwłaszcza Gereta, można wnioskować, iż ich zdaniem ponoszenie przez Prusy Królewskie jakichkolwiek ciężarów na rzecz państwa było krzywdzącą niesprawiedliwością. Taka była logika ustroju stanowego; tego typu rozumowania nie były i obce polskiej szlachcie w jej stosunku do spraw publicznych.

W punkcie II zbioru memoriał Gereta przeciw cłu generalnemu był dwujęzyczny, a jego publikacja po francusku i niemiecku miała w $1765 \mathrm{r}$. określone cele propagandowe. Rozwijając ogólne wątki swych twierdzeń ustrojowych szczególnie skoncentrował się tu Geret na dowodzeniu, iż konstytucje sejmowe w Prusach Królewskich nie obowiązują, jeżeli nie zostaną przyjęte przez sejmik generalny pruski:

„Die Landboten werden auf den Reichstag geschickt aus keiner andren Absicht, als über Vorfälle, die die Provinz betreffen, und über streitige Puncte, die sie mittelbar oder unmittelbar angesehen, zu tractiren. Alles was die Provinz angehet, nehmen die Landbothen ad referendum, um an den generalen Landtagen vorzulegen, besonders wenn es Contributionen sind" (s. 62).

Wiadomo, jak pieczołowicie chroniono w drodze liberum veto zasadę quod omnes tangit ${ }^{81}$, wiadomo także, jak daleko sięgała swoboda działanie wszystkich sejmików Rzeczypospolitej aż po r. $1717^{82}$. Nie oznaczało to oczywiście, wbrew tezom Gereta, iż konstytucje sejmowe w XVIII w. uchwalone $\mathrm{z}$ udziałem posłów pruskich miały w Prusach Królewskich nie obowiązywać ${ }^{83}$.

Kolejna trzecia rozprawa polemiczna Gereta z 1767 r. Beweis dass die Lande Preussen nicht unter der Republick Polen... stanowiła fragment jego generalnej walki w Warszawie, prowadzonej celem przekonania ambasadora rosyjskiego, iż nie wystarczy rozwiązać sprawę dysydentów po myśli ich roszczeń, ale i uwzględnić postulaty autonomistów pruskich, tj. wielkich miast pruskich. W istocie tekst ten można krótko określić jako generalną rozprawę z dekretem Zygmunta Augusta z $1569 \mathrm{r}$. o egzekucji praw w odniesieniu do Prus Królewskich, rozprawę zarówno natury formalnoprawnej - dekret był bezprawny i nie obowiązujący jak i natury merytorycznej, wykazującej, iż Prusy Królewskie powinny uzyskać względnie odzyskać liczne uprawnienia zapewniające im znaczną, jeżeli nie zupełną wręcz samodzielność wobec Korony. Strasząc swych rodaków niejasnym twierdzeniem, iż celem niecnych manewrów Korony

81 Por. przypis 32 .

82 Por. ostatnio J. Włodarczyk, Sejmiki tęczyckie, Łódź 1973, 194 n.

$83 \mathrm{Na}$ s. 65 tak Geret konkludował swe wywody: ,Eine privilegirte Provinz, wie Preussen, kann keine Gesetze und Auflagen annehmen, die ein anderes Volk macht, mit dem es selbst unzertrennlich verbunden unter einem König stehet"'. 
jest sprowadzenie Prus Królewskich (które dzieliły się na trzy województwa $\mathrm{z}$ senatorami zasiadającymi od 1569 r. w senacie Rzeczypospolitej) do roli koronnego województwa, Geret twierdził, iż nadszedł czas, by przeciwstawić się tym tendencjom i odzyskać dawną samodzielność: „die Preussen mögen von den polnischen Reichstagen verbannet werden, und ihre Comitia in Preussen mit dem Könige von Polen abwarten. Dann ist recht laut Pactio deditionis" (s. 94). Te rozważania historyczno-ustrojowe zamykają załączniki, częściowo niepublikowane w dawniejszych pracach Lengnicha ${ }^{84}$.

Sprawa reformy trybunału koronnego wracała wielokrotnie w okresie pierwszych lat rządów Stanisława Augusta. Planowano m. in. ustanowienie sesji trybunalskich dla Prus Królewskich, zgodnie z dość powszechnym życzeniem tamtejszej szlachty, w Toruniu, co wywołało ogromne oburzenie Gereta i protesty toruńskie, chociaż trybunał miał zgodnie z swymi kompetencjami rozstrzygać spory szlacheckie. Ostatecznie podjęto decyzję, wkrótce bezprzedmiotową, o ulokowaniu kadencji trybunalskich w Bydgoszczy. Z tymi to wydarzeniami wiąże się oryginalny projekt Gereta (pozycja IV zbioru) ufundowania nowego trybunału najwyższego dla Prus Królewskich właściwego zarówno dla miast, jak i szlachty. Prezesem trybunału miał zostać z urzędu biskup chełmiński, a sekretarzem przedstawiciel władz miejskich Torunia. Trybunał miał wedle projektu obradować kolejno na sesjach dla każdego województwa odrębnie (w Malborgu, Grudziądzu, Chojnicach). Celem zasadniczym projektu było zapewnienie w ramach trybunału silnej roli miast a zarazem wykluczenie możliwości jakichkolwiek apelacji do sądów koronnych.

Ostatnie dwie pozycje omawianego zbioru w mniejszej mierze zasługują na uwagę. Beredungen (pozycja V) to opracowanie w 1771 r. tekstu z XVI w. o porządku godności i urzędów pruskich zaopatrzone komentarzem Gereta. Pozycja VI przynosi in extenso wyrok sejmowy z 1643 r. ( $\mathrm{z}$ archiwum koronnego) dotyczący prawa mieszczan Prus Królewskich do dzierżenia, nabywania dóbr ziemskich i królewszczyzn, zaopatrzony odpowiednim komentarzem Gereta.

Rzucając omawiany zbiór tekstów na tło szkicowego zarysowanego stanu badań w zakresie interesującej problematyki ustroju Prus Królewskich usiłowałem wskazać na główne linie rozwojowe, jak i na konieczność podjęcia wielopłaszczyznowych badań zwłaszcza dla okresu

84 Oto wykaz tych załączników: A. Extract des Laudii Unions Animorum von dem letzten General-Landtage zu Graudenz am 7-ten Septembr. 1767. B. Extract aus der Schrift, welche die Delegirten der Lande Preussen dem Könige Sigmund I. den 3. Januar 1548 überreicht haben. C. Extract der Errinnerungs-Schrift der Preussischen Stände an den König Heinrich 1574 abgegeben. D. Extract aus einer Errinnerungs-Schrift der Preussischen Stände dem Könige Stephan 1578 abgegeben. E. Extract aus einer Protestation der Preussischen Stände. (1578). 
XVII i XVIII w. Pisma Gereta stanowią dodatkową, ważką egzemplifikację roli kierunku tzw. restauracji roszczeń autonomicznych dotąd $\mathrm{z}$ reguły wiązanego wyłącznie $\mathrm{z}$ wielką działalnością Lengnicha. Jest rzeczą jasną, iż dalsze ukonkretnienie pozycji poszczególnych wypowiedzi w okresie schyłku rządów Augusta III i pierwszej fazy rządów Stanisława Augusta wymaga nade wszystko podjęcia badań nad koncepcjami i realizacjami w polityce władz miejskich Gdańska dla okresu wykraczającego poza studium Edmunda Cieślaka o konfliktach politycznych i społecznych w Gdańsku w połowie XVIII w.

Podsumowując dotychczasowe uwagi o obozie tzw. autonomistów widzianym nade wszystko poprzez pryzmat pism Lengnicha i Gereta powiemy, iż był to w sumie w swych niektórych tezach, aspiracjach i wybuchach niezadowolenia wyraz separatyzmu niekiedy i wręcz absurdalnie dalej idący niż niektóre wystąpienia litewskie XVII-XVIII w., oparte przecież na bezdyskusyjnym politycznym i ustrojowym dualizmie Rzeczypospolitej Obojga Narodów. Teksty Gereta stanowią generalną niemal rozprawę z tendencjami do reformy państwa, jakie zarysowały się w polskim życiu publicznym po wstąpieniu na tron Stanisława Augusta. Dowodzą one, iż dla wąskich uprzywilejowanych grup patrycjatu Gdańska i Torunia sprawy wyznaniowe nie były zasadniczymi ani najważniejszymi, że decyzje $1767 \mathrm{r}$. nie rozbroiły bynajmniej ich zaciekłej opozycji, która nie miała także i charakteru narodowego (mimo pewnych akcentów ksenofobii np. u Gereta), a wywodziła się z przesłanek interesu stanowego, ekonomicznego tych grup tradycyjnego mieszczaństwa, które obawiały się, iż polityka unifikacji państwa, reformy i uzdrowienia finansów publicznych i organizacji sprawnej administracji państwowej będzie musiała doprowadzić do odebrania uzurpowanych praw bądź ograniczenia praw nabytych przed wiekami. Moje ustalenia, jak i wyniki badań dra Dygdały pozwalają zaakcentować, iż w konfederacji dysydenckiej z 1767 r. ogromne znaczenie miało podłoże społeczno-ustrojowe, rezultat działania mieszczaństwa Prus Królewskich w obronie pozycji związanych ze starym partykularnym feudalnym systemem monopolów i przywilejów i w rezultatach działanie równie może reakcyjne co i oblicze konfederacji radomskiej. W tej mierze był Geret w decydujących latach 1765-1768 znakomitym sojusznikiem reakcyjnej szlachty, nawet jeżeli jej ciemnotą gardził, a fanatyzmu katolickiego się obawiał. Był zresztą, co warto podkreślić, równie skorym do nietolerancji wobec katolików (będącej zresztą faktem w Toruniu), tej nietolerancji, której sam by padł ofiarą, gdyby nie chroniły jego miasta przywileje, uważane przezeń za niewystarczające, o których rozszerzenie walczył pod sztandarami autonomii Prus Królewskich, sugerując dla zrealizowania tego celu obalenie reform tej epoki pod wygodnym płaszczykiem propagandowym walki 
o tolerancję religijną, co pozwalało zarówno na skucesy propagandowe, jak i na bliską współpracę z ambasadorem rosyjskim.

\section{HISTOIRE DES LUTTES POUR CE QU'ON A APPELE LA RESTAURATION DES ASPIRATIONS AUTONOMES DE LA PRUSSE ROYALE AU XVIII-E S.}

R é s u mé

L'article se propose de présenter des aspects inconnus jusqu'ici de la lutte des grandes villes privilégiées de la Prusse Royale (Toruń et Gdańsk) au cours des annés 1764-1772, contre les tentatives de réformes et de centralisation de l'Etat au début du règne de Stanislas Auguste. En guise d'introduction, l'auteur présente les remarques générales sur l'état des recherches et les principaux courants de développement de ce qu'on appelait la Prusse Royale de 1455 à 1764. De plus, l'auteur entreprend la critique des ouvrages (surtout allemands) concernant le sujet. Pour apprécier comme il se doit l'histoire de la Prusse Royale, l'auteur part des opinions de Karol Górski sur la-dite union du Land de Prusse avec la Couronne jusqu'en 1569, année où, selon lui, les liens se sont resserrés et ont fait de ce territoire une des provinces de la Couronne. Pour toute la période allant de 1569 à 1772, les recherches doivent se poursuivre sur trois plans se coupant réciproquement: les prétentions et les affirmations juridiques des parties, la situation de fait, et enfin - s'il est possible de l'établir — sur le plan des prescriptions légales en vigueur. Dans les années 1764- 1772, de violentes aspirations à l'autonomie vont renaître; elles découlaient des idées et de la politique à l'époque d'Auguste III. Ces aspirations vont se heurter violemment aux tendances à la modernisation et à la réforme de l'Etat. A ce moment, Samuel Luther Geret va se trouver à la tête du mouvement, en tant que politicien, juriste et publiciste; il était le représentant du patriciat de Toruń et le continuateur radical des conceptions gouvernementales et politiques de Godefroy Lengnich. C'est à ses opinions et à son activité qu'est avant tout consacré l'article et surtout à l'analyse, omise jusqu'ici dans les recherches, du recueil publié en 1774 et intitulé: „Die aus den Gräbern durchbringende Stimme derer vor zwey hundert fünfzig Jahren verstorbenen wahren und ächten Preussen...". Les textes de Geret sont abondamment et tendancieusement illustrés d'informations historiques et de thèses juridiques. Ils constituent un débat général sur les tendances à la modernisation de la République, mais ne partent pas tellement des prémisses confessionnelles (sans parler des prémisses nationales) que de celles de la condition et de l'intérêt économique des groupes privilégiés de la bourgeoisie. Ceux-ci craignaient que la politique d'unification de l'Etat, de réforme et d'assainissment des finances conduirait à leur ôter les droits usurpés ou bien à limiter les droits acquis depuis des siècles. Par suite, Geret luttait paradoxalement pour l'extension des privilèges de la ville sous l'étendard de l'autonomie de la Prusse Royale, devenant ainsi en 1765-1768 un excellent allié de la noblesse réactionnaire, même s'il méprisait l'ignorance de celle-ci et redoutait son attitude catholique. 